\title{
MET Fusion Gene Positive
}

National Cancer Institute

\section{Source}

National Cancer Institute. MET Fusion Gene Positive. NCI Thesaurus. Code C136235.

An indication that a MET fusion gene has been detected in a sample. 